\title{
Entrepreneurial dynamics and higher education institutions in the post- communist world
}

Article

Accepted Version

Korosteleva, J. and Belitski, M. (2017) Entrepreneurial dynamics and higher education institutions in the postcommunist world. Regional Studies, 51 (3). pp. 439-453. ISSN 0034-3404 doi:

https://doi.org/10.1080/00343404.2015.1103370 Available at https://centaur.reading.ac.uk/54742/

It is advisable to refer to the publisher's version if you intend to cite from the work. See Guidance on citing.

To link to this article DOI: http://dx.doi.org/10.1080/00343404.2015.1103370

Publisher: Routledge

All outputs in CentAUR are protected by Intellectual Property Rights law, including copyright law. Copyright and IPR is retained by the creators or other copyright holders. Terms and conditions for use of this material are defined in the End User Agreement.

www.reading.ac.uk/centaur 
Central Archive at the University of Reading

Reading's research outputs online 


\title{
ENTREPRENEURIAL DYNAMICS AND HIGHER EDUCATION INSTITUTIONS IN THE POST-COMMUNIST WORLD
}

\author{
Julia Korosteleva $^{\mathrm{a}}$ and Maksim Belitski ${ }^{\mathrm{b}}$ \\ ${ }^{\mathrm{a}}$ University College London, Gower Street, London, WC1E 6BT, UK; \\ Tel. +44 (0)20 7679 8770; E-mail: j.korosteleva@ucl.ac.uk; corresponding author. \\ ${ }^{\mathrm{b}}$ University of Reading, Whiteknights, Reading, RG6 6UD, UK \\ Tel.: +44(0)118 378 6231; Email: m.belitski@ reading.ac.uk
}

\begin{abstract}
Drawing on the institutional and regional entrepreneurship literature this study develops a conceptual framework to analyse the impact of higher education institutions on entrepreneurial dynamics across the cities of the Commonwealth of Independent States (CIS) during 1995-2008. Extending upon the multi-pillar institutional concept, we find that higher education institutions play a prominent role in fostering entrepreneurial dynamics in CIS cities through multiple channels including the human capital development; shaping a system of societal values which cultivate a positive attitude towards entrepreneurship; affecting perceptions of the knowledge and skills necessary to start up a business and succeed; and knowledge spillovers.
\end{abstract}

Keywords: Entrepreneurial dynamics, small businesses, regional entrepreneurship, higher education institutions, CIS cities

JEL: L26, I23, P25 


\section{Introduction}

It has long been acknowledged that education plays an important role in the economic development, with entrepreneurship being identified as a firm-specific channel through which education may affect economic growth (AUDRETSCH and KEILBACH, 2008; DOMS et al., 2010). Generally, education has been shown to influence entrepreneurship through the education of business owners (individual level), the average level of education in the local labour market, and 'knowledge spillovers' (regional level) (DOMS et al., 2010).

At the individual level better educated individuals are more likely to start businesses and succeed (PARKER, 2009). At the regional level the relationship between education and entrepreneurship may be observed through the regional level of education ('labour pooling' effect) and 'knowledge spillovers' ('information sharing' effect). In the first instance, entrepreneurs may benefit from access to a pool of more educated workers at a lower cost (FREEDMAN, 2008; DOMS et al., 2010). In the second instance, exchange of ideas both within and across industries may generate new ideas that can help create and sustain businesses (SAXENIAN, 1994; AUDRETSCH and KEILBACH, 2007, 2008).

The academic research on the influence of education (human capital) on entrepreneurship in the regional perspective remains fairly scarce and fragmentary, being predominantly US contextualised (GLAESER et al., 2014). The objective of our study is to develop a conceptual framework to analyse the integrated complexity of the impact of higher education establishments on entrepreneurial dynamics, proxied by the growth rate of small businesses, across the cities of the Commonwealth of Independent States (CIS).

Entrepreneurial dynamism has been particularly vital for transition economies (JACKSON et al., 1999). With the collapse of communism, which was characterised by the suppression of private 
initiative, transition economies have undergone a colossal change involving comprehensive institutional reforms as they moved towards a market economy. The institutional reform of higher education institutions, whose role has been largely overlooked so far in transition economies, can be regarded as playing a prominent role in driving entrepreneurial dynamics in the region.

Through undergoing an institutional change, higher education institutions have emerged to counterbalance the Soviet legacies to the benefit of entrepreneurship development in the region.

Our conceptual framework extends upon SCOTT (1995) and STENHOLM's et al. (2013) concept of institutions. Based on these, the paper posits that higher education institutions may influence entrepreneurial dynamics through various channels such as (1) the human capital development; (2) shaping a system of societal values and norms which cultivate a positive attitude towards entrepreneurship; (3) affecting individuals' perceptions about knowledge and skills necessary to start up a business; and (4) knowledge spillovers. These correspond to STENHOLM's et al. (2013) four pillars of institutions: (1) regulative; (2) normative; (3) cognitive and (4) conducive. Formally placed within the regulative environment and mandated by national laws on education, higher education institutions have become increasingly sustained by other pillars that, taken jointly, are likely to accelerate entrepreneurial dynamics in the region.

The empirical counterpart of this analysis is based on a sample of 98 cities in 7 CIS countries, including Russia, Ukraine, Belarus, Moldova, Georgia, Armenia and Azerbaijan. We employ the System Generalised Method of Moments (SYSGMM) technique, to test our hypotheses.

This study makes several contributions to the field of entrepreneurship and institutional literature.

First of all, it adopts a more comprehensive approach in studying the impact of higher education institutions on entrepreneurship developments, drawing on the institutional and regional entrepreneurship literature. 
Second, it offers a multidimensional perspective on the role of higher education institutions, unveiling different institutional channels via which HEIs are likely to influence entrepreneurial dynamics in the region, and further measuring this effect. This allows to argue that the effect of higher education establishments goes beyond the human capital development, and manifests through other aforementioned channels. Therefore, it is important to adopt an integrated approach in studying the effect of higher education rather than narrowing it down to its single aspects. Consequently, this fills some gaps in the regional literature so far primarily focused on empirically testing only single aspects of education (DOMS et al., 2010).

Third, it further contributes to the knowledge spillover theory providing empirical evidence on the role of higher education establishments as the source for endogenous knowledge which can be potentially exploited further by would-be-entrepreneurs or facilitate the learning process of newly registered businesses increasing their chances for survival.

Fourth, this is the first empirical multi-level study of its kind on entrepreneurial dynamics in the context of the CIS cities. By discussing the institutional change and Soviet legacies, we emphasize specifically why the CIS context is unique, appropriate, and intriguing area to study the effects of higher education. The higher education system, as an institution, under a planned economy had a very distinctive set of characteristics and targets, as compared to the one prevailing in a market economy. The past two decades have seen such a colossal change in the higher education system across the region that none other developing or developed economy would have ever experienced in such a short-time horizon, and the paper argues that such an unprecedented change has brought the desirable outcome through accelerating entrepreneurial dynamics considered to be crucial for the region to drive economic growth. The use of sophisticated econometric technique and a range of controls ensure the robustness of our results in terms of their possible sensitivity to the influence of other fundamental economic and social changes 
experienced by the post-Soviet countries over the period of analysis, in particular in the first half of the 2000s.

The paper proceeds as follows. Section 2 discusses theoretical concepts which set the basis for developing our conceptual framework, and it formulates our main hypotheses. The two subsequent sections discuss data and methodology, and empirical results, whereas the last section elaborates further on the key findings of the study and provides some conclusions.

\section{Human capital and entrepreneurial dynamics}

Under human capital theory education, associated with producing skills that raise worker productivity, has been seen as a key determinant of economic performance (BECKER, 1964; VAN DER SLUIS et al., 2005). In the past decade increasing numbers of developed and emerging economies re-considered their growth patterns to be based on knowledge, technology and innovation to boost productivity levels. Knowledge, broadly divided into tacit (non-codified) and explicit knowledge (conveyed in procedures and processes), is seen as a firm's most strategically important resource (GRANT, 1996). Entrepreneurial decisions and complex problem solving utilizes an interaction of tacit and explicit knowledge (DAVIDSSON and HONING, 2003). Thus education is expected to affect entrepreneurship in a much more complex way than has been previously assumed.

Based on academic research looking at the relationship between human capital and entrepreneurship there could broadly be identifed three ways education may influence entrepreneurial activity, namely (1) owner-level education; (2) area-level education; and (3) knowledge spillovers (DOMS et al., 2010). While the former is a commonly discussed measure of human capital at an individual level, the latter two capture the effect of education at a spatial level, 
and are deeply rooted in the concept of urbanization economies. Each of these three dimensions of human capital are discussed further below.

\subsection{Owner-level education}

Empirical literature on the relationship between formal education and entrepreneurship posits that such relationship could be both negative and positive (PARKER, 2009). On the one hand side, better educated individuals are found to prefer paid employment instead of self-employment with such selection effect found to be stronger for urban residents in the context of developing countries (VAN DER SLUIS et al., 2005).

On the other hand, individuals with higher educational attainment are more likely to start a business. (see PARKER, 2009). Through formal education would-be-entrepreneurs may acquire abilities to learn about markets and technologies that enables them to better spot opportunities and launch a venture to exploit them (SHANE, 2000). Better-educated business owners are also likely to survive and grow their businesses (DOMS et al., 2010). Higher education will further increase their ability to gather necessary information in a more efficient way and learn faster to adapt to changing market conditions, and will improve their capability to solve problems and make decisions efficiently (DAVIDSSON and HONING, 2003). These are all factors that positively affect entrepreneurial dynamics.

2.2 Entrepreneurship, human capital and urbanization economies

Entrepreneurship is an urban phenomenon (BOSMA and STERNBERG, 2014). Urban areas are claimed to have higher level of 'entrepreneurial human capital' where there is a heavy concentration of skills (i.e. individuals with higher number of years of schooling) (GLAESER et 
al., 2014). Overall, urbanization economies generate various inter-industrial interactions, diversified labour markets of considerable size, substantial economies of information flows, encouraging new firm creation and positively affecting firm productivity (GLAESER et. al., 2010; BOSMA and STERNBERG, 2014).

\subsubsection{Area-level education}

Agglomerations offer the resource base and the cultural environment that facilitates the creation of new ventures and ensures their sustainability (BRIXY and GROTZ, 2007; AUDRETSCH and BELITSKI, 2013). The area-level education benefits entrepreneurs through the 'labour pooling' effect: they get access to a pool of more educated workers that have better access to information, and are better at implementing new ideas and adopting new technologies (DOMS et al., 2010). GLAESER et al. (2014) show that skills, proxied by the number of years of schooling, are positively associated with entrepreneurship and growth in productivity. Agglomeration of educated and skilled workers will also reduce the cost of searching for specialised skills (FREEDMAN, 2008; DOMS et al., 2010). Clustering of entrepreneurial activities may also speed the rate of interactions and thus promote more rapid learning increasing entrepreneurs' chances to survive and succeed (FREEDMAN, 2008).

\subsubsection{Knowledge spillovers of entrepreneurship}

By commercialising knowledge (that otherwise would remain uncommercialized) entrepreneurship is argued to serve as a conduit of knowledge spillovers (AUDRETSCH and KEILBACH, 2007, 2008). Since knowledge spillovers tend to be spatially bounded within the close proximity to the source of that knowledge, entrepreneurship opportunities, and so entrepreneurial activity, are 
greater in the contexts which are richer in knowledge (AUDRETSCH and KEILBACH, 2007; 2008).

Knowledge spillovers are seen as a central element to strategic entrepreneurship (AGARWAL et. al., 2010). However, possessing knowledge is not sufficient for generation of innovative output. AGARWAL et al. (2007) develop a model of 'creative construction' which shows how knowledge spillovers combined with an entrepreneurial action, enabling knowledge appropriation, leads to new firm creation and explains the success of industries and regions and the growth of economy as a whole.

New firms' contribution to economic growth is much stronger if they survive, succeed and grow (ACS and PLUMMER, 2005). It is economically vital for a region to ensure not only the creation of as many new firms as possible but also to ensure their sustainability to turn a region into a 'growing stock region' with 'sufficient niches and demand so that competition amongst the many new firms does not lead to a high edging out' (BRIXY and GROTZ, 2007: 296). Regions which exhibit high birth rates are also shown to have high survival rates given that a favourable environment for the founding of new firms would also stimulate the development of these firms (ibid.).

The institutional environment provides a basis for legitimacy for business operation, making it acceptable and desirable by the society (SUCHMAN, 1995). The quality of the institutional environment affects the allocation of entrepreneurial efforts among its various uses (BAUMOL, 1990), and it is particularly critical to understanding entrepreneurial developments in transition economies, given an unprecedented change they have undergone, moving towards a market economy. The latter has not only assumed the need to develop the institution of private ownership, and well-functioning financial institutions, but also, the need to undertake a reform of higher education institutions, possessing very distinctive and entrepreneurship unfriendly characteristics 
in the Soviet system. Through undergoing an institutional change, higher education institutions have emerged to play very important role in counterbalancing the Soviet legacies to the benefit of entrepreneurship development in the region, and we discuss this further below, adopting an institutional perspective on studying the effect of higher education institutions on entrepreneurial dynamics in CIS cities.

\subsection{Entrepreneurship in Emerging Markets: An Institutional Perspective}

According to JOHANNISSON (1993), 'contextual differences' play an important role in explaining spatial variations in entrepreneurship. An increasing amount of entrepreneurial research literature has focused on examining how the institutional context shapes entrepreneurship and defines its success.

The institutional theory has proven particularly useful in examining variations in entrepreneurial activity and entrepreneurs' strategies in transition countries (AIDIS et al., 2008; MANOLOVA et al., 2008; ESTRIN and MICKIEWICZ, 2011;). ESTRIN and MICKIEWICZ (2011) show that lower rates of entrepreneurial activity in the region as compared to developed economies are attributed to the negative effect of the legacy of communist planning, which needs to be replaced with market-supporting institutions.

With a slow pace CIS economies have progressed in various aspects of institutional reforms. However, establishing a well-functioning set of new formal institutions takes longer given that informal institutions, comprised of values and norms, are more durable and slowest to change (NORTH, 1990). As ESTRIN and MICKIEWICZ (2011) argue, the legacy of communism was not conducive to entrepreneurship, as reflected not just in the remnants of the command economy but more importantly by the social attitudes shaped during the communist. 
Academic research looking at the role of the institutional context in transition economies has primarily focused on studying the effects of government activism, property rights protection, availability of finance, business regulation, and the level of corruption as fundamental institutional domains affecting new firm formation and growth (PISSARIDES et al., 2003; AIDIS et al., 2008; MANOLOVA et al., 2008; ESTRIN and MICKIEWICZ, 2011). The effect of higher education institutions on entrepreneurial activity in the region has gained little attention to date. The present analysis of the role of higher education institutions on entrepreneurial dynamics across CIS cities builds upon the theoretical institutional framework originated by SCOTT (1995) and developed further in STENHOLM et al. (2013).

2.4 Higher education institutions and entrepreneurial dynamics: a multiple-pillar institutional approach

SCOTT (1995) proposes the following three crucial elements of institutions: (1) 'regulative' framework comprising regulations, laws and sanctions which are legally binding; (2) 'normative' context underpinning social values, norms and beliefs which are morally governed and culturally supported; and (3) 'cognitive' pillar constituting the 'shared logics of action' among individuals and organizations which they use in interpreting available information and formulating their expectations and response strategies. STENHOLM et. al. (2013) extend SCOTT's three-pillar model to include the 'conducive' dimension - a 'fourth institutional pillar' - which captures the conditions that primarily form the grounds for generation and dissemination of innovative ideas and technologies, stimulating the rate of high-impact entrepreneurship, regarded as an essential part of Baumol's productive entrepreneurship (AGARWAL et al., 2007; STENHOLM et. al., 2013). 
SCOTT (2008:54) argues that 'institutions supported by one pillar may as time passes and circumstances change, be sustained by different pillars'. While formally constructed within the regulatory pillar, higher education institutions are embedded in the other three pillars, notably normative, cognitive and conducive, to foster entrepreneurial activity. It is precisely this embeddedness of higher education institutions within all four institutional pillars and their ability to affect entrepreneurial dynamics through these multiple institutional dimensions that allows them to play an important role in entrepreneurship developments in the region.

\subsubsection{Regulative pillar}

Mandated by national laws on education, universities are established to facilitate the rate of human capital formation, which is an important factor influencing entrepreneurial dynamics from the area-level perspective discussed in more detail earlier. Along with affecting the supply of highlyeducated entrepreneurs, higher education establishments will affect the availability of resources available to entrepreneurs by reducing the cost of highly-skilled labour through the labour pooling effect.

We postulate our first hypothesis.

H1: Cities with stronger presence of higher education establishments are likely to have higher rate of growth in the number of small businesses.

\subsubsection{Normative pillar}

The normative institutions influence social behaviour through a system of values, beliefs and norms. They are typically viewed as the standards of behaviour established, for example, by close 
social networks (family and friends), professional associations and business groups, which underlie organizational goals and objectives (SCOTT, 1995; MANOLOVA et al., 2008). Values and beliefs of social groups influence entrepreneurial intentions to the extent of communicating a message to individual entrepreneurs of the relative desirability of their activity (KRUEGER et al., 2000). Such beliefs may be embedded in a wider setting of social references underpinned by national culture (STENHOLM et. al., 2013).

In the former Soviet Union until 1988 any kind of private business activity was regarded as illegal, and the society had a hostile attitude to entrepreneurs regarding them as speculators and associating small business with theft from the community rather than the creation of wealth and prosperity (SMALLBONE and WELTER, 2001). This soviet legacy, embedded in the sociocultural setting of CIS countries, negatively affected entrepreneurial orientations at the start of transition. It is argued that among other things a country can cultivate a positive image of entrepreneurship through the educational system (VERHEUL et al., 2002).

The whole academic tradition of the Soviet-style higher education was rigidly teachercontrolled, exam-driven and hierarchical, allowing little personal contact and limited opportunities for active learning. Lecturers primarily relied on rote learning principle based on memorisation of concepts and they discouraged critical thinking. Teaching students how to think was lacking in the Soviet tradition of higher education. The past two decades have seen some profound changes in the higher education system across the region. Neoclassical economics advocating free markets and the associated system of values (e.g. individualistic orientation, earning on merit, different thinking, risk tolerance) conducive to entrepreneurship, as well as business-related modules, including marketing, management and entrepreneurship, have become increasingly integrated in the higher education curriculums. Furthermore, the whole teaching-learning approach has 
undergone a significant change with rote learning principles being replaced with critical thinking stimulating innovative ideas and creativity, and an individualistic approach.

It has been argued that cultural values - including the degree to which people prefer to work as individuals rather than in groups, their willingness to accept inequality, tolerate risk and favour virtues of assertiveness, competition and success - influence entrepreneurial orientation (KREISER et al., 2010). More individualistically-oriented cultures with positive perceptions of uncertainty and risk taking have been shown to have a higher entrepreneurship orientation and greater appreciation of entrepreneurship (BOWEN and DE CLERCQ, 2008; KREISER et al., 2010). Respectively, the paper argues that a rapidly changing educational system in CIS countries assumes an important role of cultivating positive social attitudes towards entrepreneurial activities through communicating the benefits of entrepreneurship as an alternative occupational choice to students, and in general through a new teaching-learning approach which underlies a change in a system of values more conducive to entrepreneurship. Altogether this makes entrepreneurial activity more socially desirable. Accordingly, the next hypothesis reads as follows.

H2: The national level of higher education (independently of the effect of regional level of human capital development) is positively associated with the growth rate in the number of small businesses.

\subsubsection{Cognitive pillar}

The cognitive environment represents a common set of references, schemas and scripts specific to a socio-cultural context, and typically learned and adopted through social interactions (SCOTT, 1995; BRUTON et al., 2010; STENHOLM et al., 2013). BUSENITZ et al. (2000: 995) define the 
cognitive dimension as comprised of 'the knowledge and skills possessed by the people in a country pertaining to establishing and operating a new business'. Individuals' perceptions of knowledge and skills to start a new business are shown to direct abilities of entrepreneurs to identify new opportunities and exploit them (SHANE, 2000).

BUSENITZ et al. (2000) emphasize that perceived knowledge about starting new businesses may be particularly prevalent among individuals with higher education attainment. Education may affect individuals through providing them with a sense of autonomy and the skills which are necessary for discovering entrepreneurial opportunities (VERHEUL et al., 2002). Educational capital does not only explain entrepreneurial entry but also growth aspirations of entrepreneurs (BOWEN and DE CLERCQ, 2008), and, overall, business success, given that growth aspirations are shown to be positively associated with entrepreneurial outcomes (COVIN and WALES, 2012). BOWEN and DE CLERCQ (2008) further distinguish between 'general education' and 'specific education' (i.e. education programmes that specifically promote entrepreneurial skills). They emphasize the importance of 'specific' education in determining the allocation of entrepreneurial effort between high or low-value adding entrepreneurship.

SMALLBONE and WELTER (2006) argue that entrepreneurs in post-communist economies have higher educational attainment but lack entrepreneurial knowledge and skills given the soviet legacy of suppressed private initiative. In particular, at the start of transition throughout mid-to-late 1990s a large number of highly-educated entrepreneurs struggled to match knowledge and skills acquired through higher education with market opportunities, and they often started up low-skilled and low-value-adding businesses such as retail trade or low-tech services. With the transformation of educational system in the region there has been increasing integration of entrepreneurshiprelated modules in nationwide education curriculums, helping more individuals to acquire marketing and business management skills, expected to enhance their entrepreneurial orientation. 
Consequently, business-related education is expected to influence entrepreneurial activity by affecting individuals' knowledge and skills and preparing them to start a new venture and survive. Thus, the next hypothesis reads as follows.

H3: The greater availability of specific (business-oriented) educational programmes is likely to have a positive effect on growth in stock of small businesses.

\subsubsection{Conducive pillar}

The conducive environment, proposed by STENHOLM et al. (2013) to solve the puzzle of how the three institutional pillars shape entrepreneurial behaviour to direct entrepreneurs' efforts to productive ends, is comprised of conditions which underlie the environment filled with new opportunities created by knowledge spillovers as discussed earlier (AUDRETSCH and KEILBACH, 2007; 2008). Building upon other institutional pillars the conducive dimension captures how institutional factors shape the quality of entrepreneurial activity, or more precisely high-impact start-ups with focus on innovation and growth (STENHOLM et al., 2013). This implies that high-impact entrepreneurs do not solely benefit from regulations, normative or cognitive schemas, but their behaviour is intensified by an environment that provides 'support and interplay between innovation, skills, and resources', generating the foundation for innovativeness and dissemination of creative ideas and encouraging productive entrepreneurship (STENHOLM et al., 2013: pp.7-8). Among others such conditions include the proximity to universities and the intensity of collaboration of higher education institutions and industry that facilitate the allocation of entrepreneurial efforts towards more productive ends in the pursuit of innovative products and services, and growth (D'ESTE et al., 2012). This pillar determines the institutional capability by a 
country, region or city to develop 'strategic entrepreneurship' defined as activities based on the search of competitive advantage which through generation of new products, processes, markets, and organizational forms can lead to wealth creation sustainable in the long run (AGARWAL et al., 2007; 2010).

These insights lead to formulation of the next hypothesis.

H4: The effect of higher education institutions on entrepreneurial dynamics is reinforced through university-manufacturing industry collaboration.

Drawing on the above discussion highlighting the role of higher education institutions on entrepreneurial dynamics within the four institutional dimensions, this study further adopts an integrated approach in studying its effect on entrepreneurship across CIS cities. Through undergoing an institutional change higher education establishments emerge to counterbalance the Soviet legacies to the benefit of entrepreneurship development in the region. They may influence entrepreneurial dynamics through various channels such as (1) human capital development at a regional level; (2) shaping a system of societal values and norms which cultivate a positive attitude towards entrepreneurship; (3) affecting individuals' perceptions about knowledge and skills necessary to start up a business and to adapt to changes to survive via offering more businessoriented courses; (4) knowledge spillovers occurring to manufacturing industry through closer university-industry collaboration. Figure 1 summarises this conceptual model visually.

2.5 Control variables 
Earlier academic research on regional variation in entrepreneurship shows that a number of factors are likely to influence cross-city variation. These can be broadly grouped as socio-economic city characteristics and agglomeration economies controls; and business environment indicators.

As far as the former is concerned, the study introduces a city-level GDP per resident to control for the city economic development stage. A decrease in stock of small businesses is expected with an increase in a city-level GDP per resident, reflecting growth of established businesses and the importance of economies of scale. This will raise the competitive pressure, driving less efficient firms out of the market. We also introduce the GDP annual growth rate variable (at a city level) to control for cyclical economic performance.

Along with the level of income and GDP growth rate, this analysis also considers unemployment as part of the socio-economic characteristics of cities to be a likely determinant of entrepreneurial dynamics. The effect of the rate of unemployment is ambiguous. On the one hand, it may have a push effect with entrepreneurship being seen as the only available occupational alternative. On the other hand, it may simply mirror economic recession and demand deficiency, adversely affecting the rate of growth in the number of small businesses.

This study also controls for capital investment to GDP ratio at a city level to capture the availability of financial resources in CIS cities. Although generally expected to have a positive effect on entrepreneurial dynamics, the role of capital investment in the context of the CIS cities may be ambiguous, and the possibility of a crowding out effect as a result of public funds being channelled to support large-scale state-owned enterprises is not excluded.

Finally, the level of criminality in cities is likely to affect the growth in stock of small businesses negatively, reflecting the higher probability of asset expropriation by private parties (ROSENTHAL and ROSS, 2010). 
Among agglomeration economies controls we introduce population density to control for a market size and the effect of consumer demand, and air pollution is used to capture the effect of industrial agglomeration in CIS cities.

As regards business regulative environment, it may simultaneously enhance entrepreneurial activity and constrain it. Based on earlier empirical research on entrepreneurship this study identifies the following dimensions of business environment as likely to affect the rate of change in small businesses: property rights protection; government activism; banking sector reform; and business regulation.

Strong property rights are important for entrepreneurial activity to the extent that in the first place property rights guarantee the status quo via providing crucial security of private property against an arbitrary action of the executive branch of the government (ACEMOGLU and JOHNSON, 2005). Strong property rights protection is likely to incentivise the growth rate in small businesses in CIS cities.

Another important aspect of the regulatory environment is the level of government activism, expected to adversely affect entrepreneurship in CIS cities. As the state sector grows, it crowds out private activity, absorbing a larger proportion of the resources of the economy (ESTRIN et al. 2013). Furthermore, higher tax income, associated with greater government expenditures, and higher marginal tax rates for higher earners are also likely to reduce the expected returns to entrepreneurs, increasing the opportunity cost of switching to entrepreneurship (PARKER, 2009).

Better developed financial institutions, to the extent of mitigating external finance constraints, are found to disproportionally benefit smaller firms (BECK et al., 2005). With wider supply of finance and competition, the financial institutions are pushed to choose more risky financial options including entrepreneurial finance (KOROSTELEVA and MICKIEWICZ, 2011). This is particularly topical for transition economies, for which scarcity of financial resources is 
documented as one of the major obstacles for entrepreneurship development (PISSARIDES et al., 2003). Therefore, progress in banking reform is likely to be positively associated with entrepreneurship in CIS cities.

Finally, more flexible business regulations are expected to foster the growth rate of small businesses Viewing regulation as benign and socially inefficient, and likely to be captured by the industry, it is likely to benefit industry incumbents the most rather than start-ups (see DJANKOV et al., 2002). .

This study also controls for industry composition, country, and time effects.

3. Data and methodology

\subsection{Sample Description}

To investigate variation in the rate of growth in small businesses across CIS cities this work utilises the 1995-2008 data collected from the Offices of National Statistics in Russia, Ukraine, Belarus, Moldova, Georgia, Armenia and Azerbaijan. The data was collected by local research officers formally employed by the respective Regional Statistical offices. This initiative was funded by project No 09-9031 entitled 'Driving urban economic growth - evidence from transition economies' as a part of the larger project 'Cities: An Analysis of the Post-Communist Experience' (2009-2010), supported by the Economics Education and Research Consortium in co-operation with the Global Development Network.

The dataset contains urban audit indicators across various domains specific to our study, including higher education institutional measures at a city level related to our main hypotheses (e.g. presence of higher education establishments in a city; number of MBA programmes); and economic and social characteristics of cities and other indicators used as controls. The dataset is represented by 98 cities covering Russia (54 cities), Belarus (6 cities), Ukraine (26 cities), 
Moldova (1 city-capital), Georgia (5 cities), Armenia (5 cities), Azerbaijan (1 city-capital) (see Appendix A). The city-level data was merged with institutional country-level data, derived from the Polity IV dataset ${ }^{1}$, Heritage Foundation ${ }^{2}$, EBRD transition indicators (EBRD Transition Reports, various issues), to also shed light on the effect of institutional settings at a country level on entrepreneurial dynamics.

\subsection{Variable Definition}

We use the rate of change in the number of small businesses as the dependent variable, proxied by the difference between the natural logarithms of the current level of small businesses and its level in the previous year. According to national statistical offices small businesses are defined as firms with 50 employees or less (100 employees respectively in manufacturing sector). Appendix B illustrates the change in the number of small businesses over the period 1995-2006.

The number of universities in the CIS cities (regional level), obtained from the "Universities in CIS" and "Universities worldwide information resources" databases, ${ }^{3}$ is used to test Hypothesis 1. The incidence (a number) of HEIs has been used in the previous academic research to capture the effect of higher education on new business formation in innovative industries (see, FRITSCH and AAMOUCKE (2013)). Interesting enough, it is precisely the presence (and size) of public academic institutions (rather than ups than indicators that reflect the quality of these institutions) were shown to have a significant effect on the formation of innovative start-ups (ibid.). 
The tertiary education enrolment rate, proxied by the logarithm of the number of students enrolled in tertiary education per 100,000 residents (country level) andobtained from UNESCO Institute for Statistics, is introduced to test Hypothesis 2.

The effect of specific (business-oriented) education is tested via the number of MBA programmes offered by business schools and other higher education establishments in each city (Hypothesis 3). This variable is obtained from the MBA studies guide and Global MBA and Master Programs Directory, and university web-sites in CIS countries. Expansion in MBA programmes, not existent in the Soviet times, is not only expected to harness managerial skills necessary for successfully running a business, but also is important for equipping students with basic practice-oriented skills of how to set up a new venture (see VARBLANE and METS, 2010).

Finally, interacting the university variable with the manufacturing industry control variable allows to capture the effect of university-industry collaboration (Hypothesis 4), Universities may serve as a conduit of knowledge generated in research labs, university departments and applied in small-scale factories and workshops, to contribute to business development, including the establishment of new SEs (RODRÍGUEZ-POSE and CRESCENZI, 2008; PONDS et al., 2010).

For the strength of property rights we use the Polity IV measure of efficient constraints on the arbitrary power of the executive branch of the government, named "constrains on executive". The size of the local government is proxied by city-level government expenditures as a proportion of city-level GDP..

The effect of banking reform is controlled via employing the EBRD transition indicator, scored from 1 denoting little progress from a socialist banking system apart from the separation of the central bank and commercial banks to 4+ representing a fully-fledged market economy with the institutional standards and norms of an industrialised market economy. 
The Heritage Foundation business freedom index is utilized to measure the rigidity of business regulation. It reflects various barriers to start, operate and exit business, and it scores from 0 to 100 with 100 denoting the highest degree of business freedom (BEACH and KANE, 2008).

Table 1 reports variable definitions, including other control variables. Appendix $\mathrm{C}$ shows the correlation matrix between variables and descriptive statistics used in this study.

\{Table 1 to be inserted here $\}$

\subsection{Methodology}

The model to examine the determinants of entrepreneurial activity in a panel of 98 cities during 1995-2008, is specified as follows.

$$
\begin{aligned}
& \mathrm{dLnSE}_{\mathrm{it}=} \beta_{1} \mathrm{LnS}_{\mathrm{it}-1}+\beta_{2} \mathrm{X}_{\mathrm{it}}+\beta_{3} \mathrm{Z}_{\mathrm{it}}+\mathrm{u}_{\mathrm{it}}(1), \quad \mathrm{i}=1, \ldots, \mathrm{N} ; \mathrm{t}=1, \ldots, \mathrm{T} \\
& \mathrm{u}_{\mathrm{it}}=\mathrm{v}_{\mathrm{i}}+\mathrm{e}_{\mathrm{it}}(2)
\end{aligned}
$$

where $\mathrm{dLnSE}_{\mathrm{it}}$ is the rate of change in the number of small businesses at city level, $\mathrm{LnS}_{\mathrm{it}-1}$ is a lagged value of the number of small businesses taken in logs (predetermined variable). $\mathrm{X}_{\mathrm{it}}$ is a vector of four potentially endogenous variables, namely GDP per resident, GDP growth rate, the rate of unemployment, and the ratio of capital expenditure to GDP. $Z_{\text {it }}$ is a vector of strictly exogenous control variables.

The error term $\mathrm{u}_{\mathrm{it}}$ consists of the unobserved city-specific effects, $\mathrm{v}_{\mathrm{i}}$ and the observationspecific errors, $\mathrm{e}_{\mathrm{it}}$. The examples of unobservable city-specific effects, captured by the $\mathrm{v}_{\mathrm{i}}$, can be specific cultural characteristics of cities, their governance efficiency and other factors that cannot 
be directly controlled for in the model, as they are unobservable. We also include fixed country and time effects to control for unobserved heterogeneity across a sample of our countries, and over time.

The dynamic structure of equation (1) makes both the OLS and fixed effects estimators upwards and downwards biased respectively, and inconsistent, since the predetermined variable and endogenous variables are correlated with the error term. Therefore, to estimate equation (1) we use the System Generalised Method of Moments (SYS GMM) estimator (BLUNDELL and BOND, 1998). The use of this estimator allows us to address econometric problems which arise from the estimating equation (1). These include (a) the problem of potential endogeneity of some of our regressors identified above; (b) the presence of predetermined variables - the lagged dependent variable $\mathrm{LnS}_{\mathrm{it}-1}$ that gives rise to measurement error as it is correlated with past errors; (c) the presence of fixed effects which may be correlated with the repressors; (d) a finite sample. SYS GMM allows the predetermined and endogenous variables in levels to be instrumented with suitable lags of their own differences (ROODMAN, 2006).

To resolve the problem of potential multicollinearity between a tertiary education enrolment variable and unemployment rate (see correlation matrix reported in Appendix C), we check the robustness of the results to exclusion of the unemployment rate in specifications containing a tertiary education enrolment variable. In the absence of the rate of unemployment economic cyclicality is controlled via GDP growth rate.

\section{Empirical results and discussion}

The empirical results are summarized in Table 2 reporting the results based on the three estimation methods, notably pooled OLS (specification 1); (2) panel fixed effects (specification 2); and (3) 
System GMM estimation (specifications 3-7). Comparing the results of all three estimators used, one can see that the results obtained from the System GMM model (specification 3) are superior given that: (a) the autoregressive term is positive and significant, and its value lies between the respective terms obtained by fixed effects (which provides the lower bound) and OLS (which provides the upper bound); (b) there are gains in efficiency; (3) the instrument set is valid as evidenced by the Hansen test of overidentified restrictions; (4) all variables of interest have expected signs. Thus the discussion of the results proceeds based on specifications (3-7).

\{Table 2 to be inserted here $\}$

This study finds that entrepreneurial dynamics in CIS cities are largely explained by the presence of higher education institutions in a city, affecting both the demand and supply side of entrepreneurship via the higher level of human capital development (Hypothesis 1) (Spec 3).

We also find support for Hypothesis 2, implying that the more students enrolled in tertiary education at the national level, the higher is the rate of growth in the number of small businesses in a city. The rapidly changing higher education system is likely to breed a new generation of individuals possessing knowledge that makes them appreciate entrepreneurship and communicate its benefits to other members of the society.

The robustness of the above results to multicollinearity (discussed in the methodology section) is further tested by excluding the rate of unemployment from the model (specification 5). The results remain robust.

We also confirm Hypothesis 3, showing the important role of targeted (business-oriented) education (specification 6$)^{4}$. The university variable was excluded from this specification given its high correlation with the number of MBA programmes in a specific city and the high presence of higher education establishments. These findings suggest that formal university education is also 
likely to influence individuals' perceived knowledge and skills needed to start-up a new venture and succeed.

Finally, in specification 7 the study tests whether the effect of higher education institutions could be further reinforced through university-manufacturing industry collaboration (Hypothesis 4). Indeed, we confirm that the effect of the higher presence of universities in a city is strengthened by university-manufacturing industry collaboration which retains its significance in the presence of the control for human capital. More specifically, a unit increase in the number of universities, given an average level of manufacturing sector as a share in GDP equal to $12.77 \%$, will result in $0.1 \%$ increase in the number of SEs. The marginal effect of a city-level HEI is further illustrated graphically, allowing for the variation in the number of universities across a valid range of values; in Appendix D knowledge spillovers are shown to enhance the direct effect of city-level HEI on entrepreneurship rate, and this effect is statistically significant. Furthermore, cities with higher than average level of manufacturing in GDP demonstrate a significant and positive association between change in SEs and a marginal change in the number of universities (Appendix E).

Overall, we interpret this result as evidence for the importance of agglomeration economies in terms of higher concentration of knowledge, which may lead to intensified exchange of ideas via collaboration between small businesses and research institutions. This is an important advancement given state centralisation of research and development activities in the past. In summary, tighter links between universities and industry may facilitate the development of strategic entrepreneurship in the region (STENHOLM et al., 2013).

Table 3 provides a summary of the results of HEIs on entrepreneurial dynamics. As one can see the effect of HEI manifests through more than one channel with both a number of city-level MBA programmes and the incidence of HEI in cities having the strongest effect. This leads to the 
conclusion that higher education institutions are likely to affect entrepreneurial dynamics though various channels which are important to assess jointly.

As regards other control variables our study fails to find any evidence of the significance of market size, proxied by the logarithm of population density. We find a significant and positive effect of air pollution, used as a proxy for industrial agglomeration effects. The results do not show any significant effect of capital investment and the rate of unemployment. The rate of growth in small businesses is negatively associated with the level of GDP per capita. This reflects that CIS cities exhibit signs of an efficiency-driven stage of economic development, where economies of scale prevail constituting an entry barrier for small businesses. This study also finds some fragmentary support for GDP growth rate, but fails to find any significant effect of the rate of criminality.

Now we turn to the discussion of the business environment. Similarly to AIDIS et al. (2012) this work finds some support for the effect of property rights protection on the rate of change in the number of small businesses. The findings also suggest that larger size of the state discourages growth in stock of small businesses. Entrepreneurial dynamics are found to positively associated with the progress in banking reform that promotes financial development, in particularly benefiting small firms. Our results also provide some fragmentary weak support for more flexible business regulations encouraging growth in stock of small businesses.

\section{CONCLUSIONS}

In this research we develop a comprehensive framework showing the effect of higher education institutions on entrepreneurial dynamics in the spatial context of Commonwealth of Independent States. 
To develop the conceptual framework this study draws upon the institutional concept proposed by SCOTT (1995) and STENHOLM et al. (2013) advocating that the institutional environment is comprised of four key pillars including regulatory, normative, cognitive and conducive domains. We further extend this theory to highlight the important role of higher education institutions that, while formally constructed within the regulative pillar, are embedded within the other three pillars to facilitate the creation of the environment conducive to formation of new firms and their sustainability.

Higher education institutions are shown to affect entrepreneurial dynamics through the following channels: (1) human capital development; (2) shaping a system of societal values and norms which cultivate a positive attitude towards entrepreneurship; (3) affecting individuals' perceptions about knowledge and skills necessary to start up a business and to adapt to changes to survive; and (4) knowledge spillovers which occur through close collaboration between small businesses and research institutions, and which have been actively promoted now in the CIS region via establishment of clusters, including, for example, the Skolkovo innovation hub in Moscow, and its equivalent in Minsk.

These findings have important policy implications. To promote sustainable growth in the region local authorities should further invest in higher education. As advocated by BOWEN and DE CLERCQ, 2008 and SAXENIAN, 2007 to generate higher returns, this investment should specifically target entrepreneurial education, but should not be confined to business students only. Furthermore, to promote strategic entrepreneurship the local authorities should concentrate on encouraging cluster development between universities and local businesses.

Overall, the embeddedness of higher education institutions within all four institutional pillars makes them well placed to accelerate the development of environment conducive to positive 
entrepreneurial dynamics. These results are robust to potential effect of other factors that largely shaped the development of entrepreneurship at the time of the study.

In addition, our results provide evidence on the importance of some other domains of regulatory environment for studying entrepreneurial dynamics in the region. More specifically, this study shows that greater government activism, associated with a higher ability of governmental officials to transfer wealth through various corruptive practices, reduces growth in stock of small businesses, whereas progress in banking reform and secure property rights enhances it. Finally, we also find some fragmentary support for the positive role of flexible business regulations on entrepreneurial dynamics in CIS region.

\section{NOTES}

1. See MARSHALL M. and JAGGERS K. (2009) Polity IV Project: Political Regime Characteristics and Transitions, 1800-2008, Dataset Users' Manual. (available at: http://www.systemicpeace.org/polity/polity4.htm).

2. For discussion see BEACH and KANE, 2008.

3. For more detailed information please see http://univer.in and http://univ.cc.

4. Given that MBA programmes equivalent to a Western style MBAs were introduced in the former Soviet Union countries largely in the 2000s, the paper tests the robustness of the results restricting the sample to 2000-2008; and 2005-2008, confirming their robustness (available upon request from the authors).

\section{ACKNOWLEDGEMENTS}


The authors acknowledge the financial support of the Global Development Network jointly with its regional partners in the Commonwealth of Independent States and Central Eastern Europe, including The Economics Education and Research Consortium (EERC), Kyiv School of Economics (KSE) and CERGE-EI University as part of a larger project entitled "Cities: An Analysis of the Post-Communist Experience" (grant number R09-9031). 


\section{REFERENCES}

ACEMOGLU D. and JOHNSON S. (2005) Unbundling institutions, Journal of Political Economy 113, 943-995.

ACS Z. and PLUMMER L. (2005) Penetrating the "Knowledge Filter" in Regional Economies. The Annals of Regional Science 39(3), 439-456.

AGARWAL R., AUDRETSCH D.B. and SARKAR M. (2007) The Process of Creative Construction: Knowledge Spillovers, Entrepreneurship and Economic Growth, Strategic Entrepreneurship Journal 1(3-4), 263-286.

AGARWAL R., AUDRETSCH D.B. and SARKAR M. (2010) Knowledge Spillovers and Strategic Entrepreneurship, Strategic Entrepreneurship Journal 4, 271-283.

AIDIS R., ESTRIN S. and MICKIEWICZ T. (2008) Institutions and entrepreneurship development in Russia: a comparative perspective, Journal of Business Venturing 23, 656-672.

AIDIS R., ESTRIN S. and MICKIEWICZ T. (2012) Size matters: entrepreneurial entry and government, Small Business Economics 39, 119-139.

AUDRETSCH D.B. and KEILBACH M. (2007) The Theory of Knowledge Spillover Entrepreneurship, Journal of Management Studies 44(7), 1242-1254.

AUDRETSCH D.B. and KEILBACH M. (2008) Resolving the knowledge paradox: Knowledgespillover entrepreneurship and economic growth, Research Policy 37, 1697-1705.

AUDRETSCH D.B. and BELITSKI, M. (2013) The missing pillar: the creativity theory of knowledge spillover entrepreneurship, Small Business Economics 41(4), 819-836.

BAUMOL W. (1990) Entrepreneurship: productive, unproductive, and destructive, Journal of Political Economy 98 (5), 893-921. 
BEACH W. and KANE T. (2008) Methodology: Measuring the 10 Economic Freedoms, in HOLMES K.E. and FEULNER O'GRADY M. (Eds) 2008 Index of Economic Freedom, pp. 3955. The Heritage Foundation, Washington D.C.

BECK T., DEMIRGÜÇ-KUNT A. and MAKSIMOVIC V. (2005) Financial and Legal Constraints to Growth: Does the Firm Size Matter? The Journal of Finance 60(1), 137-177.

BECKER G.S. (1964) Human capital. Columbia University Press, New York.

BLUNDELL R. and BOND S. (1998) Initial conditions and moment restrictions in dynamic panel data models. Journal of Econometrics 87, 111-143.

BOSMA N. and STERNBERG R. (2014) Entrepreneurship as an urban event? Empirical evidence from European cities, Regional Studies 48(6), 1016-1033.

BOWEN H. and DECLERCQ D. (2008) Institutional Context and the Allocation of Entrepreneurial Effort, Journal of International Business Studies 39(4), 747-767.

BRIXY U. and GROTZ R (2007) Regional patterns and determinants of the success of new firms in Western Germany. Entrepreneurship and Regional Development 19 (4), 293-312.

BUSENITZ L., GOMEZ C. and SPENCER J. (2000) Country Institutional Profiles: Unlocking Entrepreneurial Phenomena, Academy of Management Journal 43(5), 994-1003.

COVIN J. and WALES W. (2012) The Measurement of Entrepreneurial Orientation, Entrepreneurship Theory and Practice 36(4), 677-702.

DAVIDSSON P. and HONIG B. (2003) The Role of Social and Human Capital amongst Nascent Entrepreneurs, Journal of Business Venturing 18(3), 301-331.

D'ESTE P., GUY F. and IAMMARINO S. (2012) Shaping the formation of university-industry research collaborations: what type of proximity does really matter? Journal of Economic Geography. doi: 10.1093/jeg/lbs010, 1-22 
DJANKOV S., LAPORTA R., LOPEZ-DE-SILANES F. and SHLEIFER A. (2002) The regulation of entry, Quarterly Journal of Economics CXVII (1), 1-36.

DOMS M. E., LEWIS E. and ROBB A. (2010) Local Labour Force Education, New Business Characteristics, and Firm Performance, Journal of Urban Economics 67, 61-77.

ESTRIN S. and MICKIEWICZ T. (2011) Entrepreneurship in transition economies: the role of institutions and generational change, in MINNITI M. (Eds) The Dynamics of Entrepreneurship, pp. 293-338. Oxford University Press, Oxford.

ESTRIN S, KOROSTELEVA J, MICKIEWICZ T. (2013) Which Institutions Encourage Entrepreneurs to Create Larger Firms? Journal of Business Venturing 28, 564-580.

FELDMAN M.P. and AUDRETSCH D.B. (1999) Innovation in cities: science-based diversity, specialization and localized competition, European Economic Review 43, 409-429.

FREEDMAN M. (2008) Job Hopping, Earnings, Dynamics, and Industrial Agglomeration in the Software Publishing Industry, Journal of Urban Economics 64(3), 590-600.

FRITSCH M. and AAMOUCKE R. (2013) Regional public research, higher education, and innovative start-ups - an empirical investigation, Small Business Economics 41, 865-885.

GLAESER E.L., ROSENTHAL S. and STRANGE W. (2010) Urban economics and entrepreneurship, Journal of Urban Economics 67(1), 1-14.

GLAESER E.L., PONZETTO G. and TOBIO K. (2014) Cities, Skills and Regional Change, Regional Studies 48, 7-43.

GRANT R.M. (1996) Towards knowledge based theory of the firm. Strategic Management Journal 17, 109-122. 
JACKSON J.E., KLICH J. and POZNANSKA K. (1999) Firm Creation and Economic Transitions, Journal of Business Venturing 15(5-6), 427-450.

JOHANNISSON B. (1993) Designing Supportive Contexts for Emerging Enterprises, in KARLSSON C., JOHANNISSON B. and STOREY D. (Eds) Small Business Dynamics, pp. 117142. Routledge, London.

KOROSTELEVA J. and MICKIEWICZ T. (2011) Start-up Finance in the Age of Globalisation. Emerging Markets Finance and Trade 47(3), 23-49.

KRUEGER N., REILlY M. and CARSRUD A. (2000) Competing Models of Entrepreneurial Intentions. Journal of Business Venturing 15(5-6), 411-432.

KREISER P.M., MARINO L.D., DICKSON P. and WEAVER K.M. (2010) Cultural Influences on Entrepreneurial Orientation: The Impact of National Culture on Risk Taking and Proactiveness in SMEs, Entrepreneurship Theory and Practice 34(5), 959-983.

MANOLOVA T., EUNNI R. GYOSHEV B. (2008) Institutional Environments for Entrepreneurship: Evidence from Emerging Economies in Eastern Europe, Entrepreneurship Theory and Practice 32(1), 203-218.

NORTH D. (1990) Institutions, Institutional Change and Economic Performance. Cambridge University Press, Cambridge.

PARKER S. C. (2009) The Economics of Entrepreneurship. Cambridge University Press, Cambridge.

PISSARIDES F., SINGER M. and SVEJNAR J. (2003) Objectives and Constraints of Entrepreneurs: Evidence from Small and Medium Size Enterprises in Russia and Bulgaria, Journal of Comparative Economics 31, 503-531. 
PONDS R., VAN OORT F. and FRENKEN K. (2010) Innovation, spillovers and universityindustry collaboration: an extended knowledge production function approach. Journal of Economic Geography 10(2), 231-255.

RODRÍGUEZ-POSE A. and CRESCENZI R. (2008). Research and development, spillovers, innovation systems, and the genesis of regional growth in Europe, Regional studies 42(1), 51-67.

ROODMAN D. (2006) How to Do xtabond2: An Introduction to "Difference" and "System" GMM in Stata, Working Paper 103, Centre for global development.

ROSENTHAL S. and ROSS A. (2010) Violent crime, entrepreneurship and vibrant cities, Journal of Urban Economics 67(1), 135-149.

SAXENIAN A. (1994) Regional Advantage: Culture and Competition in Silicon Valley and Route 128. Harvard University, Cambridge, MA.

SAXENIAN A. (2007) The New Argonauts: Regional Advantage in a Global Economy. Harvard University Press, Cambridge, MA.

SHANE S. (2000) Prior Knowledge and the Discovery of Entrepreneurial Opportunities, Organization Science 11(4), 448-469.

SCOTT W. (1995) Institutions and Organizations. Sage Publications, Thousand Oaks, CA.

SCOTT W. (2008) Institutions and Organizations: Ideas and Interests. Sage Publications, $3^{\text {rd }}$ ed. Thousand Oaks, CA.

VAN DER SLUIS J., VAN PRAAG M. and VIJVERBERG W. (2005) Entrepreneurship, selection and performance: a meta-analysis of the impact of education in less developed countries, World Bank Economic Review 19, 225-261.

SMALLBONE D. and WELTER F. (2001) The Distinctiveness of Entrepreneurship in Transition Economies, Small Business Economics 16(4), 249-262. 
SMALLBONE D. and WELTER F. (2006) Conceptualizing entrepreneurship in a transition context, International Journal of Entrepreneurship and Small Business 3(2), 190-206.

STENHOLM P., ACS Z. and WUEBKER R. (2013) Exploring Country-level Institutional Arrangements on the Rate and Type of Entrepreneurial Activity, Journal of Business Venturing 28, 176-193.

SUCHMAN M. (1995) Managing Legitimacy: Strategic and Institutional Approaches, Academy of Management Review 20(3), 571-610.

VARBLANE U. and METS T. (2010) Entrepreneurship education in the higher education institutions (HEIs) of post-communist European countries, Journal of Enterprising Communities: People and Places in the Global Economy 4(3), 204-219.

VERHEUL I., WENNEKERS S., AUDRETSCH D.B. and THURIK R. (2002) An Eclectic Theory of Entrepreneurship: Policies, Institutions and Culture, in AUDRETSCH D.B., THURIK R., VERHEUL I. and WENNEKERS S. (Eds) Entrepreneurship: Determinants and Policy in a European-U.S. Comparison, pp.11-82. Kluwer Academic Publishers, Norwell, MA.

WOOLDRIDGE J. M. (2009) On estimating firm-level production functions using proxy variables to control for unobservables, Economics Letters 104(3), 112-114. 